\title{
Perbedaan Hasil Belajar Fisika Melalui Model Pembelajaran Kooperatif Tipe Numbered Heads Together (NHT) Berbantuan Kartu Soal dengan Model Pembelajaran Direct Instruction Di SMAN 7 Mataram Tahun Ajaran 2015/2016
}

\author{
Febri Susanti ${ }^{1}$, Syahrial Ayub ${ }^{2}$, Muhammad Taufik ${ }^{2}$ \\ ${ }^{1}$ Alumni Program Studi Pendidikan Fisika \\ ${ }^{2}$ Dosen Program Studi Pendidikan Fisika \\ FKIP Universitas Mataram \\ Mataram, Indonesia \\ Email: Febri2526@gmail.com
}

\begin{abstract}
This research is aimed to know the difference between physics learning result through numbered heads together type cooperative learning model helped by question card and physics learning result through direct instruction learning model at SMAN 7 Mataram on academic year of 2015/2016. This research was an experimental study with pretest posttest control group design. The population in this research was all the students of XI IPA SMAN 7 Mataram. Based on sampling process using cluster random sampling tehnique, XI IPA 7 was choosen as the experiment A class and XI IPA 6 was choosen as the experiment B class. The result of the test analized using t-test polled varians showed that $t_{\text {count }}$ was 5,98 and table was 1,99 in the significant level of $5 \%$ with the degree of freedom (df) of 61. Since $t_{\text {count }}>t_{\text {table, }} H_{o}$ was rejected and $H_{a}$ was accepted. It can be concluded that there were a difference between physics learning result through numbered heads together type cooperative learning model helped by question card and physics learning result through direct instruction learning model at SMAN 7 Mataram on academic year of 2015/2016.
\end{abstract}

Keywords: numbered heads together type cooperative learning model, physics learning result

\section{PENDAHULUAN}

Fisika adalah kumpulan pengetahuan, cara berfikir, dan penyelidikan. Fisika dipandang sebagai suatu proses dan sekaligus produk sehingga dalam pembelajarannya harus mempertimbangkan strategi atau metode pembelajaran yang efektif dan efisien.

Pembelajaran fisika yang efektif dan efisien dapat diciptakan, salah satunya dengan menggunakan metode atau model pembelajaran yang bervariasi. Guru harus bisa memilih metode atau model pembelajaran yang tepat agar tercapai hasil yang maksimal dan pembelajaran berhasil sesuai yang direncanakan.

Berdasarkan hasil observasi yang dilakukan peneliti saat pelaksanaan kegiatan PPL, dari kelas XI IPA 1 sampai dengan XI IPA 7 tidak banyak siswa yang menyukai mata pelajaran fisika. Siswa menganggap fisika sebagai mata pelajaran yang sulit dan membosankan. Hal ini terjadi karena pemilihan metode atau model pembelajaran yang kurang tepat saat mengajarkan beberapa materi fisika. Tidak dapat dipungkiri bahwa model pembelajaran yang digunakan oleh seorang guru dapat mempengaruhi minat dan motivasi siswa dalam mengikuti pembelajaran. Apabila model pembelajaran yang digunakan kurang tepat, maka siswa menjadi tidak antusias dan kurang termotivasi untuk belajar sehingga siswa tidak dapat memahami materi dengan baik. Siswa yang kurang mampu memahami materi, akan mengalami kesulitan dalam mengerjakan soal latihan ataupun soal ulangan. Sehingga berdampak pada hasil belajar fisika yang rendah. Saat proses pembelajaran fisika di kelas ada beberapa masalah yang ditemukan peneliti. Permasalahan pertama, ketika guru menjelaskan materi hanya sedikit siswa yang memperhatikan. Kedua, ketika guru meminta siswa untuk mencatat hanya sebagian siswa yang mencatat walaupun mereka tidak mengetahui apa maksud yang dicatatnya. Ketiga, siswa tidak berani bertanya kepada guru apa yang belum mereka pahami. Keempat, ketika guru meminta siswa untuk maju ke depan kelas untuk menjelaskan jawaban dari persoalan yang diberikan, hanya beberapa siswa saja yang berani sedangkan yang lain hanya diam walaupun sebenarnya mereka sanggup, hal tersebut terjadi 
karena siswa takut salah dan tidak percaya diri. Akibatnya hanya sedikit siswa yang aktif sedangkan sisanya ada yang sibuk sendiri, mengganggu temannya yang lain, mengobrol, bahkan tidak betah berada di dalam kelas ketika pelajaran sedang berlangsung.

Selain itu, siswa juga sering mengalami kesulitan dalam menyelesaikan masalah-masalah fisika, siswa cenderung terpaku pada cara penyelesian masalah yang diberikan oleh guru dan tidak berani mencoba dengan cara yang lain. Hal tersebut tidak lain karena proses belajar yang mereka alami sewaktu berada di kelas X dengan menggunakan metode atau model pembelajaran yang selalu sama disetiap pertemuannya. Sehingga proses seperti ini menjadi kebiasaan mereka selama belajar di sekolah. Hal ini tentu berpengaruh terhadap hasil belajar fisika siswa.

Berdasarkan pada beberapa persoalan di atas peneliti menawarkan suatu solusi alternatif yakni dengan menggunakan model pembelajaran kooperatif yang dapat menciptakan suasana belajar harmonis, kondusif, dan menyenangkan sehingga dapat meningkatkan minat dan motivasi belajar siswa yang tentunya juga dapat meningkatan hasil belajar siswa. Dalam pembelajaran kooperatif, siswa secara heterogen terbagi dalam beberapa kelompok. Setiap kelompok akan mengerjakan soal yang diberikan untuk kelompoknya dengan harapan siswa akan dapat bekerja bersama teman sekelompoknya. Pembelajaran kooperatif ini berbeda dengan belajar kelompok pada umumnya yang tidak semua siswa mau bekerja bersama kelompoknya, karena biasanya ada saja siswa yang tidak ikut membantu menyelesaikan soal yang diberikan.

Hal ini yang menjadi salah satu alasan peneliti memilih model pembelajaran kooperatif, khususnya tipe Numbered Heads Together. Model pembelajaran kooperatif tipe Numbered Heads Together ini menjadikan semua siswa dalam kelompoknya mempunyai tanggung jawab masing-masing, karena siswa akan dipanggil secara acak sesuai nomor soal yang mereka dapatkan sehingga mereka harus mempersiapkan diri agar dapat menjawab pertanyaan dan mereka akan berpikir banyak untuk keberhasilan kelompoknya. Model pembelajaran Numbered Heads Together ini merupakan sebuah model pembelajaran kooperatif yang menekankan pada struktur-struktur khusus yang dirancang untuk mempengaruhi pola-pola interaksi siswa yang memiliki tujuan untuk meningkatkan penguasaan akademik. Penerapan pembelajaran Numbered
Heads Together memiliki interaksi siswa dengan siswa lebih besar dibandingkan interaksi siswa dengan guru. Hal ini menyebabkan siswa lebih banyak belajar dengan sesama siswa daripada belajar dengan guru [1]. Sehingga siswa yang merasa belum mampu dan takut bila bertanya menjadi berani bertanya karena yang dihadapi adalah temannya sendiri. Dengan demikian siswa akan termotivasi belajar dan menjadi lebih paham.

Untuk mengoptimalkan model pembelajaran Numbered Heads Together ini, peneliti menggunakan media kartu soal sebagai sarana pertanyaan dari guru untuk siswa saat pemanggilan nomor secara acak. Dengan anggapan bahwa siswa akan lebih tertarik pada soal yang tertulis di kartu daripada soal yang diberikan dalam bentuk lembaran atau yang tertulis di papan tulis.

Model pembelajaran dengan media seperti ini yang diharapkan dapat meningkatkan pemahaman siswa terhadap materi fisika yang diajarkan, sehingga nantinya akan berdampak pada peningkatkan hasil belajar siswa. Berdasarkan uraian di atas peneliti merasa tertarik untuk mengadakan penelitian dengan judul "perbedaan hasil belajar fisika melalui model pembelajaran kooperatif tipe numbered heads together (NHT) berbantuan kartu soal dengan model pembelajaran direct instruction di SMAN 7 Mataram Tahun Ajaran 2015/2016"

\section{TINJAUAN PUSTAKA}

Numbered Heads Together adalah model pembelajaran kooperatif yang dirancang untuk mempengaruhi pola interaksi siswa dan sebagai alternatif terhadap struktur kelas tradisional. Hal ini dilakukan agar dapat melibatkan lebih banyak siswa dalam menelaah materi yang tercakup dalam suatu pelajaran dan mengecek pemahaman mereka terhadap isi pelajaran. Ada 4 fase pembelajaranan NHT yaitu penomoran, mengajukan pertanyaan, berpikir bersama, dan menjawab [2].

Kartu soal adalah sejenis permainan dalam pembelajaran dengan menggunakan media kartu soal yang disajikan berdasarkan nomor kartu dan dibagikan pada seluruh siswa secara berkelompok [3]. Kartu soal berfungsi untuk membagikan secara acak permasalahan yang sebelumnya telah dipaparkan guru untuk didiskusikan dalam kelompok atau dapat juga digunakan untuk membagikan soal-soal kepada setiap kelompok atau individu dimana setiap soal 
memiliki poin tertentu yang bisa didapatkan oleh kelompok tersebut apabila berhasil menjawabnya [4].

Hasil belajar adalah pola-pola perbuatan, nilai-nilai, pengertian-pengertian, sikap-sikap, apresiasi dan keterampilan. Menurut bloom, hasil belajar mencakup kemampuan kognitif, afektif, dan psikomotorik. Domain kognitif mencakup knowledge (pengetahuan, ingatan), comprehension (pemahaman, menjelaskan, meringkas, contoh), application (menerapkan), analysis (menguraikan, menentukan hubungan), synthesis (mengorganisasikan, merencanakan, membentuk bangunan baru), dan evaluation (menilai) [5].

Direct Instruction adalah model pengajaran yang bersifat teacher center. Penyebutan itu mengacu pada gaya mengajar di mana guru terlibat aktif dalam mengusung isi pelajaran kepada siswa dan mengajarkannya secara langsung kepada siswa [6]. Model direct interaction dapat berbentuk demonstrasi, pelatihan atau praktik, kerja kelompok dan ceramah [7].

\section{METODE PENELITIAN}

Penelitian eksperimen ini merupakan suatu cara untuk menguji hubungan sebab-akibat, dimana peneliti memberikan perlakuan (treatment) kepada subjek, sekelompok subjek atau partisipan atau kondisi, alat dan bahan tertentu untuk menentukan apakah perlakuan tersebut memiliki dampak atau faktor hasil tertentu [8]. Penelitian ini dilaksanakan dari Oktober 2015 sampai dengan Juni 2016 bertempat di SMAN 7 Mataram. Desain penelitian menggunakan Pre-Test Post-Test Control Group Design. Populasi dalam penelitian ini yaitu seluruh siswa kelas XI IPA SMAN 7 Mataram yang terbagi dalam 7 kelas. Teknik pengambilan sampel menggunakan cluster random sampling sehingga diperoleh kelas XI IPA 7 sebagai kelas eksperimen A dan kelas XI IPA 6 sebagai kelas eksperimen B. Kelas eksperimen A diberi perlakuan model pembelajaran kooperatif tipe NHT berbantuan kartu soal, sedangkan kelas eksperimen B menggunakan pembelajaran konvensional dengan model direct instruction.

Pengumpulan data dalam penelitian ini dilakukan dengan metode tes menggunakan tes pilihan ganda sebanyak 25 soal yang telah dipilih sesuai kriteria analisis uji instrumen, meliputi analisis validitas, reliabilitas, taraf kesukaran, dan daya beda soal. Tes dilakukan sebanyak dua kali yakni tes awal (pre-test) dan tes akhir (post-test). Pre-test dilakukan sebelum kegiatan pembelajaran untuk mengetahui kemampuan awal siswa terhadap materi pelajaran. Analisis data hasil pre-test meliputi uji homogenitas dan uji normalitas. Sementara itu, post-test dimaksudkan untuk mengetahui hasil belajar siswa terhadap materi pelajaran setelah kegiatan pembelajaran. Analisis data hasil post-test meliputi uji normalitas dan uji hipotesis. Uji normalitas digunakan untuk mengetahui normalitas data guna menentukan uji statistik dalam uji hipotesis. Uji homogenitas untuk uji lanjut statistik parametrik yang digunakan jika data terdistribusi normal. Uji hipotesis dilakukan untuk mengetahui pengaruh model pembelajaran berbasis masalah dengan metode eksperimen terhadap hasil belajar fisika siswa.

\section{HASIL DAN PEMBAHASAN}

Hasil penelitian ini berupa data tes hasil belajar yang menunjukkan kemampuan akhir siswa setelah mengikuti pembelajaran, sehingga dapat dilihat perbedaan hasil belajar fisika siswa antara kelas eksperimen A dan kelas eksperimen B pada materi momentum dan impuls. Data hasil belajar fisika siswa terdiri dari hasil pre-test dan post-test dapat dilihat dalam tabel 1 dan tabel 2 berikut.

Tabel 1 Hasil Pre-Test Kelas Eksperimen A dan Eksperimen B

\begin{tabular}{lcc}
\hline Komponen & \multicolumn{2}{c}{ Pre-test } \\
& Eksperimen & Eksperimen \\
& A & B \\
\hline Jumlah siswa & 32 & 31 \\
Rata-rata & 39,50 & 38,05
\end{tabular}

Tabel 1 Hasil Pre-Test Kelas Eksperimen A dan Eksperimen B (Lanjutan)

\begin{tabular}{lcc}
\hline \multirow{2}{*}{ Komponen } & \multicolumn{2}{c}{ Pre-test } \\
\cline { 2 - 3 } & $\begin{array}{c}\text { Eksperimen } \\
\text { A }\end{array}$ & $\begin{array}{c}\text { Eksperimen } \\
\text { B }\end{array}$ \\
\hline Nilai & 52 & 48 \\
tertinggi & 12 & 16 \\
Nilai & & \\
terendah & & Normal \\
Uji & Normal & \\
Normalitas & & Homogen \\
Uji & Homogen & \\
Homogenitas & & \\
\hline
\end{tabular}


Tabel 2 Hasil Post-Test Kelas Eksperimen A dan Eksperimen B

\begin{tabular}{lcc}
\hline \multicolumn{1}{c}{ Komponen } & \multicolumn{2}{c}{ Post-test } \\
& Eksperimen A & Eksperime \\
& \multicolumn{3}{c}{ B } \\
\hline Jumlah siswa & 32 & 31 \\
Rata-rata & 79,19 & 68,77 \\
Nilai tertinggi & 88 & 76 \\
Nilai terendah & 60 & 56 \\
Uji Normalitas & Normal & Normal \\
Uji t-test polled & $t_{\text {hitung }}>t_{\text {tabel }}, \mathrm{H}_{\mathrm{o}}$ ditolak dan $\mathrm{H}_{\mathrm{a}}$ \\
varians & diterima & \\
\hline
\end{tabular}

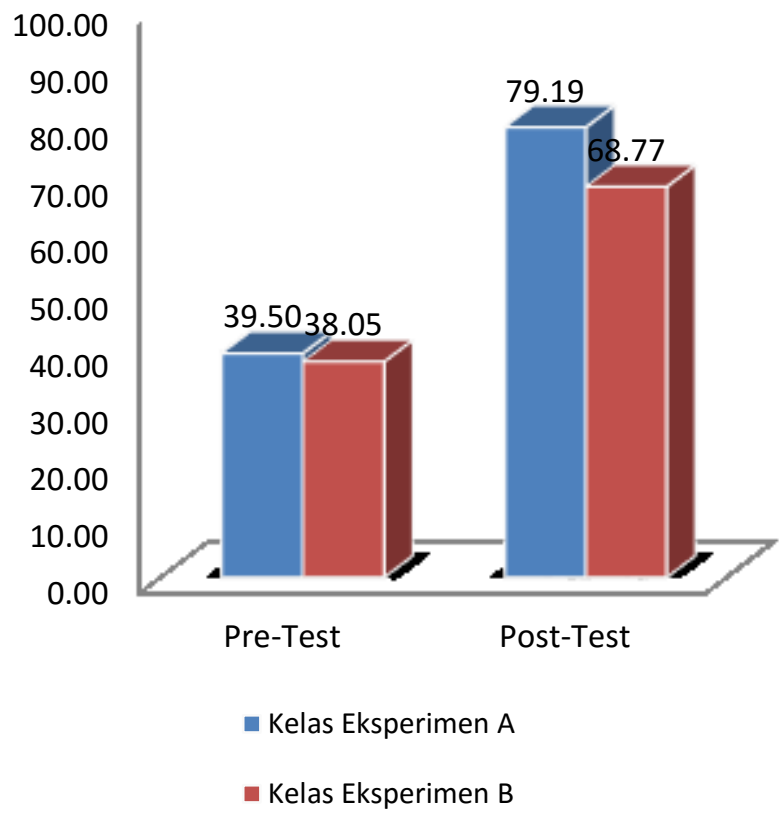

$(39,50)$. Namun nilai rata-rata kedua kelas masih berkategori rendah tetapi data kedua dinyatakan homogen dan normal. Hal ini berarti kedua kelas memiliki kemampuam awal yang sama dan data terdistribusi normal.

Hasil post-test pada tabel 2, memperlihatkan bahwa nilai rata-rata kelas eksperimen A $(79,19)$ lebih tinggi dari kelas eksperimen B $(68,77)$. Hasil ini menunjukkan bahwa kedua kelas sama-sama mengalami peningkatan. Namun peningkatan nilai pada kelas eksperimen A lebih tinggi dari kelas eksperimen B.

Hasil post-test kemudian dihitung normalitas datanya menggunakan rumus chikuadrat, diperoleh bahwa data kedua kelas adalah normal. Hal ini berarti uji hipotesis menggunakan statistik parametrik.

Hasil perhitungan uji homogenitas diperoleh bahwa kedua kelas adalah homogen, berarti statistik parametrik yang digunakan yaitu, t-test polled varians pada taraf signifikan $5 \%$. Uji hipotesis menggunakan t-test polled varians diperoleh $t_{\text {hitung }}=5,98$ lebih besar dari $t_{\text {tabel }}=1,99$. Hal ini berarti terdapat perbedaan hasil belajar fisika melalui model pembelajaran kooperatif tipe Numbered Heads Together (NHT) berbantuan kartu soal dengan model pembelajaran Direct Instruction di SMAN 7 mataram tahun ajaran 2015/2016.

Nilai rata-rata pre-test dan post-test hasil belajar fisika kedua kelas berdasarkan tabel 1 dan tabel 2 diatas dapat juga disajikan seperti pada gambar 1 berikut ini.

\section{Gambar 1 Histogram Nilai Rata-rata Pre-Test dan Post-Test Hasil Belajar Fisika Siswa Kelas Eksperimen A dan kelas eksperimen B}

Kelas eksperimen A yang menggunakan model pembelajaran kooperatif tipe Numbered Heads Together (NHT) berbantuan kartu soal membuat lebih banyak siswa untuk aktif dibandingkan dengan kelas ekperimen $\mathrm{B}$ yang menggunakan pembelajaran (konvensional) dengan model Direct Instruction. Model pembelajaran kooperatif tipe Numbered Heads Together (NHT) berbantuan kartu soal juga memberikan lebih banyak peluang kepada siswa untuk berpartisipasi dalam proses belajar. Siswa belajar untuk menemukan jawaban dari soal/permasalahan yang diberikan dan berusaha untuk memahami serta menguasainya sehingga siswa mendapat pengalaman yang bermakna dan pengetahuannya lebih melekat dalam ingatan yang tentunya berdampak positif pada hasil belajar.

Pada awal pembelajaran model Numbered Heads Together (NHT) berbantuan kartu soal di kelas eksperimen A, siswa diberikan penjelasan mengenai materi yang akan dipelajari, setelah itu siswa pada masing-masing kelompok yang telah terbentuk diberikan nomor. Setiap anggota kelompok diberikan kartu soal sesuai dengan nomor yang didapatkan. Kartu soal adalah sarana/media pembelajaran yang dibuat dalam bentuk kertas tebal berbentuk persegi 
panjang berisi gambar dan soal berupa pertanyaan yang dapat merangsang pikiran, perhatian, dan minat siswa sehingga siswa merasa senang dan tidak bosan dalam belajar. Dalam hal ini, kartu soal digunakan untuk membagi soal-soal secara acak untuk didiskusikan dalam kelompok. Setiap siswa memiliki tanggung jawab pada kelompoknya untuk menjawab soal yang mereka dapatkan. Tidak jarang siswa yang belum mengerti atau belum bisa mengerjakan soal bertanya pada anggota yang lain sehingga tercipta interaksi saling ketergantungan positif antar siswa dalam sebuah kelompok. Selanjutnya tiap kelompok berdiskusi untuk membahas jawaban dan memastikan anggota kelompoknya mengetahui jawaban tersebut. Disini siswa dituntut untuk bekerjasama menjawab permasalahan yang diberikan kepada kelompoknya sehingga tidak ada siswa yang pasif, semua siswa terlibat dalam proses pembelajaran. Disamping itu siswa juga harus benar-benar memahami serta menguasai jawaban tersebut. Karena pemanggilan nomor dipilih secara acak, dan tidak ada siswa yang tahu siapa yang akan maju kedepan menjelaskan jawaban, maka semua harus siap ketika nomornya dipanggil.

Berbeda dengan siswa di kelas ekperimen B yang menggunakan pembelajaran (konvensional) yaitu yang biasa digunakan di sekolah dengan model Direct Instruction. Di awal pembelajaran, siswa diberikan penjelasan mengenai materi yang akan di pelajari, setelah itu siswa dibimbing mengerjakan soal-soal latihan. Pemberian latihan soal ini berbeda dengan di kelas eksperimen A, soalnya sama tetapi penyajian soalnya yang berbeda. Disini soal disajikan menggunakan media papan tulis sehingga membuat siswa menjadi bosan dan malas dalam belajar. Saat guru memberikan latihan soal, ada saja siswa yang tidak mau mengerjakan, namun ada juga yang mengerjakan tetapi dengan menyontek temannya tanpa ingin tahu caranya, yang penting tugasnya selesai. Di sini, proses penyelesaian latihan soal juga begitu lambat karena siswa hanya menunggu guru untuk membimbingnya. Ketika waktu pembelajaran hampir selesai sementara soal latihan masih ada yang belum terjawab, maka untuk menyelesaikannya tepat waktu guru lah yang mengerjakan kembali latihan soal tersebut. Hal inilah yang menjadikan siswa pasif, hanya beberapa orang saja yang terlihat aktif, dan yang lain hanya mendengarkan. Sehingga tidak mengherankan hasil belajar fisika pada kelas ekperimen $\mathrm{B}$ lebih rendah dibandingkan dengan kelas eksperimen A, karena siswa dikelas eksperimen A lebih aktif dan juga banyak bertanya.

Model pembelajaran kooperatif tipe Numbered Heads Together (NHT) berbantuan kartu soal memiliki beberapa kelebihan, diantaranya adalah siswa yang belajar melalui model Numbered Heads Together (NHT) berbantuan kartu soal memiliki motivasi belajar yang lebih tinggi dibandingkan siswa dengan pembelajaran (konvensional) Direct Instruction. Hal ini karena proses pembelajaran model Numbered Heads Together (NHT) berbantuan kartu soal melatih siswa untuk selalu siap dan aktif dalam proses pembelajaran, siswa juga merasa senang ketika terlibat langsung dalam belajar, sedangkan siswa yang belajar dengan pembelajaran (konvensional) Direct Instruction memiliki motivasi belajar yang rendah karena posisi siswa adalah sebagai penerima pelajaran atau hanya sebagai pendengar (siswa pasif). Selain itu, model Numbered Heads Together (NHT) berbantuan kartu soal lebih memprioritaskan pemahaman siswa, karena siswa memang harus benar-benar paham dan siap ketika dipanggil untuk menjelaskan jawaban di depan kelas. Hal ini berdampak positif pada hasil belajar di kelas eksperimen A yang lebih baik dibandingkan dengan kelas ekperimen B.

Berdasarkan penjelasan diatas bahwa model pembelajaran kooperatif tipe Numbered Heads Together (NHT) berbantuan kartu soal yang diterapkan pada kelas eksperimen A lebih baik daripada pembelajaran (konvensional) dengan model Direct Instruction yang digunakan pada kelas ekperimen B. Hal ini sesuai dengan penelitian yang telah dilakukan oleh [9] hasil belajar siswa yang menggunakan model pembelajaran NHT lebih baik daripada pembelajaran konvensional. [10] Menunjukkan bahwa terjadi peningkatan hasil belajar yang signifikan menggunakan pembelajaran kooperatif model NHT. [11] Menunjukkan bahwa model kooperatif tipe NHT dapat meningkatkan hasil belajar. Hal yang sama juga dikatakan [12] dan [13], yaitu pembelajaran yang menggunakan model tipe NHT dapat meningkatkan hasil belajar siswa. Selain model

pembelajaran kooperatif tipe NHT memberikan hasil yang positif terhadap hasil belajar, media 
kartu soal juga memberikan pengaruh terhadap hasil belajar. Hal ini sesuai dengan penelitian yang telah dilakukan oleh [14] dan [15], bahwa pembelajaran menggunakan media kartu soal dapat memberikan prestasi/hasil belajar yang tinggi atau dengan kata lain dapat meningkatkan hasil belajar siswa.

\section{PENUTUP}

Pada taraf signifikan $5 \%$ terdapat perbedaan hasil belajar fisika melalui model pembelajaran kooperatif tipe Numbered Heads Together (NHT) berbantuan kartu soal dengan model pembelajaran Direct Instruction di SMAN 7 mataram tahun ajaran 2015/2016.

Model pembelajaran kooperatif tipe Numbered Heads Together (NHT) berbantuan kartu soal dapat dijadikan sebagai alternatif model pembelajaran yang dapat diterapkan untuk mengaktifkan siswa, sehingga hasil belajar kognitif siswa meningkat. Penerapan model pembelajaran kooperatif tipe Numbered Heads Together (NHT) harus memperhatikan beberapa hal, yaitu: 1) Diperlukan perencanaan dan persiapan yang matang sebelum diterapkan di kelas agar dapat berjalan sesuai dengan tujuan pembelajaran yang hendak dicapai. 2) Alokasi waktu diatur sebaik mungkin sehingga tiap tahap pembelajaran dapat berlangsung secara optimal. 3) Model dan design kartu soal dapat dikembangkan lagi agar lebih menarik perhatian dan minat siswa dalam belajar. 4) Teknik pengelolaan kelas.

\section{UCAPAN TERIMAKASIH}

Terima kasih penulis sampaikan kepada Bapak Dr. H. Wildan, M.Pd., Dr. Drs. Karnan, M.Si., Dr. Ahmad Harjono, S.Si., M.Pd., Syahrial Ayub, S.Pd., M.Si., Muhammad taufik, S.Pd., M.Si., serta semua pihak yang telah membantu penelitian ini.

\section{REFERENSI}

[1] Wijaya, A. 2010. Keaktifan Model Pembelajaran Kooperatif Tipe Numbered Heads Together (NHT) Terhadap Kemampuan Pemecahan Masalah Belajar Siswa. Jurnal. Volume 10. Nomor 2. Semarang : JPTM UNS.

[2] Trianto. 2011. Model-Model Pembelajaran Inovatif Berorientasi Kontrutivistik. Jakarta : Prestasi Pustaka.
[3] Said, A. dan Budimanjaya, A. 2015. 95 Strategi Mengajar Multiple Intelligences. Jakarta : Pranamedia Group.

[4] Berliana. 2008. Pembelajaran Tematik Siswa Kelas 3 SDN 1 Surodakan Trenggalek Melalui Strategi Belajar Kelompok Dengan Media Kartu Soal Tahun Pelajaran 2007-2008. Skripsi. Jember : IKIP PGRI.

[5] Suprijono, A. 2013. Cooperative Learning. Yogyakarta : Pustaka Pelajar.

[6] Trianto. 2011. Model-Model Pembelajaran Inovatif Berorientasi Kontrutivistik.

[7] Sahidu. 2014. Pengembangan Program Pembelajaran Fisika (P3F). Mataram : FKIP PRESS.

[8] Setyosari, P. 2013. Metode Penelitian Pendidikan dan Pengembangan. Jakarta : Kencana.

[9] Wijayati, N. 2008. Penggunaan Model Pembelajaran Numbered Heads Together Untuk Meningkatkan Hasil Belajar Kimia. Jurnal. Volume 2. Nomor 2. Semarang : Universitas Negri Semarang.

[10] Widodo, S. 2011. Penerapan Pembelajaran Kooperatif Tipe Numbered Heads Together Untuk Meningkatkan Hasil Belajar Siswa Kelas VII SMP Pada Pokok Bahasan Besaran Dan Pengukuran. Jurnal. Volume 7. Semarang : Universitas Negri Semarang.

[11] Hutahaean, J dan Ratna, S.D. 2014. Pengaruh Model Pembelajaran Kooperatif Tipe Numbered Heads Together (NHT) Dengan Menggunakan Media Mind Mapping Terhadap Hasil Belajar Siswa Kelas XI Semester 2 Pada Materi Pokok Fluida Statis Di SMAN 10 Medan TP 2013/2014. Jurnal. Volume 2. Nomor 4. Medan : Universitas Negri Medan.

[12] Hakim, A. dan Rambe, D. 2012. Perbedaan Hasil Belajar Fisika Dengan Menggunakan Model Pembelajaran Kooperatif Tipe NHT Dan Model Konvensional Pada Materi Besaran Dan Satuan. Jurnal. Volume 1. Nomor 2. Medan : Universitas Negri Medan.

[13] Dharmawati, A. 2013. Penerapan Pembelajaran Numbered Heads Together 
Berbantuan Question And Answer Card Pada Materi Hidrokarbon. Jurnal. Volume 7. Nomor 7. Semarang : Universiteas Negri Semarang.

[14] Prasetyaningrum, D. 2013. Studi Komparasi Metode Pembelajaran Teams Games Tournament (TGT) Disertai Media Kartu Soal Dan Roda Impian Terhadap Prestasi Belajar Siswa Pada Materi Pokok Hidrokarbon Kelas X Sman 7 Surakarta Tahun Pelajaran 2012/2013. Jurnal. Volume 2. Nomor 3. Surakarta : Universitas Sebelas Maret.

[15] Rositawati, H. 2015. Penggunaan Model Pembelajaran TAI ( Team Assisted Individualization) Dilengkapi Dengan Media Kartu Soal Untuk Meningkatkan Interaksi Sosial Dan Prestasi Belajar Pada Materi Hukum Dasar Dan Konsep Mol Kels X SMAN Kebakkramat Tahun Pelajaran 2014/2015. Jurnal. Volume 4. Nomor 4. Surakarta : Universitas Sebelas Maret.

\section{BIOGRAFI PENULIS}

Febri Susanti, lahir desa Leneng kabupaten Lombok Tengah 25 Februari 1994. Penulis telah menyelesaikan pendidikan di SDN 2 Leneng, SMPN 1 Praya, dan SMAN 1 Praya. Kemudian melanjutkan studinya di FKIP Universitas Mataram pada Program Studi Pendidikan Fisika (Alumni 2012, lulus Juli 2016). 